\title{
Role Of Insulin Like Growth Factor-1 and Insulin Like Growth Factor Binding Protein-3 In Patients Of Coronary Artery Disease Attending Suez Canal University Hospital
}

\author{
Emad F Ismail ${ }^{1}$, Amany Y El Kazaz ${ }^{1}$, Ahmed T ElSerafi, \\ May IAbd EI All ${ }^{2}$ and Gamela M Nasr ${ }^{3}$ \\ ${ }^{1}$ Medical Biochemistry Department ${ }^{2}$, Faculty of Pharmacy, 6 October \\ University, ${ }^{3}$ Cardiology Department, ${ }^{1,3}$ Faculty of Medicine, Suez \\ Canal University, Ismailia, Egyp.
}

\begin{abstract}
Cardiovascular disease is the leading cause of mortality, not only in the Western world, but also in developing countries. It has been suggested that circulating insulin like growth factor-1 (IGF-I) and insulin like growth factor binding protein-3(IGFBP3) are involved in the pathophysiological processes underlying coronary artery disease. We evaluated the relationship between the levels of IGF-I and IGFBP-3 nd coronary atherosclerosis in sixty two patients attending Cardiac Clinic and Coronary Care Unit at Suez Canal University Hospital, and 30 healthy controls. IGF-1 and IGFBP-3 were measured using Immulite 1000. Fasting blood glucose and lipid profile were measured for all subjects. Coronary artery disease was more frequent among males compared to females $(67.7 \%$, and $32.3 \%$ respectively). Total cholesterol (TC), low density lipoprotein cholesterol (LDLc) and triacylglycerol (TAG) levels were significantly higher, while HDL was significantly lower in patients than controls. The means of IGF-1 and IGFBP-3 were significantly higher among control group compared to patients group $(212.5 \pm 109.1 \mathrm{ng} / \mathrm{ml}$ and $6.4 \pm 2.3 \mathrm{ng} / \mathrm{ml}$ versus $129.5 \pm 66.2 \mathrm{ng} / \mathrm{ml}$., $4.4 \pm 1.6 \mathrm{ng} / \mathrm{ml}$ respectively, $p=0.001$ for each). Thirty $(48.4 \%)$ of patients had 3 stenosed vessels. The mean percent of stenosis was $74.7 \pm 14.2 \%$. IGF-1 and IGFBP-3 were lower in the group of three affected vessels but there was no significant correlation between both parameters and severity of the disease. There was significant correlation between IGF-1 and HDL $(\boldsymbol{r}=\mathbf{0 . 2 5 4}$, -value $=0.046)$ in patients group while no significant correlation between IGF-1 and other parameters in both groups. There was no significant correlation between IGFBP-3 and other parameters in both groups. In conclusion, IGF-1, IGFBP-3 may be used to determine the risk of coronary artery disease in Egyptian population living in Suez Canal area.
\end{abstract}

Key Words: IGF-1, IGFBP-3and CAD.

\section{INTRODUCTION}

Traditionally, atherosclerotic disease is considered a typical middle- age disease. The most common heart disease is coronary artery disease (CAD), which often appears as a heart $\operatorname{attack}^{(1)}$. 
The atherosclerotic process starts decades before the appearance of clinical symptoms (myocardial infarction, cerebral vascular accident and peripheral vascular disease). The progression and the severity of the atherosclerotic process are related to the presence, number, magnitude and duration of a series of risk factors ${ }^{(2)}$.

Cardiovascular disease is the leading cause of mortality, not only in the Western world, but also in developing countries. Coronary artery disease is a global health concern today, with limited treatment options available to address that disorder. Extensive efforts have been devoted to molecular therapies to enhance perfusion and function of the ischemic myocardium $^{(3)}$.

Insulin-like growth factor I (IGFI) is a peptide hormone that shares sequence homology with insulin and has a fundamental role in somatic growth and cellular differentiation, metabolism and survival ${ }^{(4)}$.

IGF-1 is expressed, under GH (growth hormone) control, by the liver in an endocrine form or ubiquitously in a relevant 'paracrine/autocrine' fashion $^{(5)}$.

Besides the liver, important contributions to serum IGF-1 levels come from bone, vascular endothelium and exercising skeletal muscle $^{(6)}$ to give a total daily secretion of approx. 3-10 mg/day ${ }^{(7)}$.

Daily IGF-1 serum preservation/tissue delivery is supervised by six different specific high-affinity binding proteins (IGFBP-1 to IGFBP-6), synthesized mainly by the liver, which can bind IGF-1 in biological fluids, regulating its movement between intravascular and extravascular compartments, increasing its half-life, and managing IGF delivery to tissues by fine-tuning its concentrations in the interstitial fluid and its affinity for receptors ${ }^{(8)}$.

The majority of IGFs in the circulation are bound to IGF binding proteins, of which IGF binding protein 3 (IGFBP-3) is the most predominant, carrying $>80 \%$ of circulating IGF-I. But, although IGFBP-3 is an important regulator of the bioactivity of IGF-I, there is evidence to suggest that IGFBP-3 possesses functions independent of its role as an IGF-I carrier protein ${ }^{(9)}$.

It has been suggested that circulating IGF-I is involved in the pathophysiological processes underlying coronary artery disease (CAD). Experimental data in animals have shown that overexpression or administration of IGF-I after myocardial infarction (MI) prevents cardiomyocytes death and improves cardiac function ${ }^{(\mathbf{1 0 , 1 1})}$.

Evidence for improvement of cardiac function and increased ventricular mass has been shown in individuals with growth hormone deficiency after short-term IGF-I therapy (12). Improved cardiac performance has also been demonstrated following administration of recombinant IGF-I to individuals with chronic heart failure ${ }^{(\mathbf{1 3})}$.

Several potential protective mechanisms of IGF-I on vascular disease processes have been described. Experimental infarction models suggest that IGF-I may promote survival of myocytes exposed to ischemic injury in part by enhancing glucose uptake ${ }^{(14)}$. 
Cross sectional observational studies have reported that circulating IGF-I concentrations are lower in individuals with $\mathrm{CAD}$ and $\mathrm{MI}{ }^{(15-17)}$, but the opposite has been reported as well ${ }^{(18)}$. Furthermore, increments in IGF-I levels are associated with reduced prevalence of atherosclerotic plaques, as measured by arterial ultrasound ${ }^{(19)}$.

The prospective association between circulating levels of IGF-I and IGFBP-3 and subsequent risk of future $\mathrm{CAD}$, however, remains uncertain ${ }^{(20-25)}$.

Several population-based prospective studies have suggested that low circulating levels of IGF-I within the normal range may predict increased risk of ischemic heart disease ${ }^{(22,26}$ ) and ischemic stroke: IGFBP-3 levels have been both directly and inversely associated with prevalent and incident $\mathrm{CVD}^{(27,28)}$.

IGF-1 deficiency may precipitate the apoptosis of smooth muscle cells migrating to the endothelial layer, as well as the cells found in the media of the vessel. This probably contributes to the destabilization of atherosclerotic plaque ${ }^{(29)}$. IGF-1 prevents the dilatation of heart muscle by activating cardiac progenitor cells and inhibiting apoptosis of cardiomyocytes and VSMC hypertrophy ${ }^{(30)}$.

IGF-1 has also been shown to play a critical role in the reduction of ischemia/reperfusion damage, LV (left ventricular) dysfunction remodeling and in the recovery of ischemic cardiomyopathy through a reduction in apoptosis and apoptosis-induced inflammation. Moreover, IGF-1 enhances cardiomyocyte contractility and relaxation ${ }^{(8)}$.

In a mouse model of diabetic cardiomyopathy, the induced expression of the IGF-1R gene prevented the onset of diastolic dysfunction, fibrosis and preserved cardiac function ${ }^{(31)}$. That low serum IGF-1 levels are able to predict the future onset of ischemic heart disease (IHD), heart failure (HF), and cardiovascular and all-cause mortality $(21,22,32-37)$.

Two isolated exceptions have described no $(n=1122)^{(38)}$ or inverse $(n=642)^{(20)}$ prospective associations between IGF-1 levels and all-cause and cardiovascular mortality.

A third case is that of a prospective study $(n=1273)$ describing a more complex relation, in which low IGF-1 levels predicted allcause mortality, and both low-normal and high-normal IGF-1 levels predicted IHD mortality ${ }^{(39)}$.

Delafontaine et al., ${ }^{(30)}$ have reported that low systemic levels of IGF-1 and high systemic levels of IGF binding protein- 3 (IGFBP3) were direct risk factors for coronary artery disease $^{(30)}$.

The role of IGF-1 in the progression of coronary atherosclerosis is unclear ${ }^{(29)}$.

These conflicting results leave the role of IGF-1 levels in coronary atherosclerosis an unresolved question. So, the aim of the present work is to determine the relationship between the levels of IGF--1 and IGFBP3-3 and coronary atherosclerosis in Suez Canal area. 


\section{MATERIALS \& METHODS}

Sixty two patients presented with coronary artery disease were recruited from Cardiac Clinic and Coronary Care Unit at Suez Canal University Hospital in the period from October 2011 to February 2012. Coronary artery disease was diagnosed by coronary angiography. Patient's age ranged 36-75 years. Control group consisted of 30 volunteers with no history of coronary artery disease or family history of that disease. Their age ranged 35-67 years. The protocol was approved by the local Ethical Committee. They were enrolled in the study after obtaining informed consent. The two groups were subjected to the following: Detailed history taking including (personal history, present history of coronary artery disease, presence of chronic diseases \{as diabetes mellitus, hypertension ... $\}$ and family history). Clinical examination included anthropometric measurements weight, height measurements and the body mass index was calculated as weight $(\mathrm{Kg})$ / square of height $\left(\mathrm{m}^{2}\right)$.

Laboratory investigations including:

- Measurements of IGF-1 and IGFBP-3 using Immulite/Immulite1000 IGF-1kit (PILKGF-9,2005-10-12) and IGFBP-3 kit (PILKGB-6,2005-0808) (Siemens, Immulite).

- Fasting blood glucose was determined by glucose oxidase method $^{(40)}$.

- Lipid profile: Serum total cholesterol $\quad(\mathrm{TC})^{(41)}$, and triacylglycerol (TAG) ${ }^{42}$, were estimated colorimetrically and HDL- cholesterol (HDLc) $)^{(\mathbf{4 4})}$ was determined enzymatically ${ }^{(43)}$, while LDL- cholesterol (LDLc) was calculated by the Friedewald formula ${ }^{(44)}$.

\section{Statistical analysis:}

The obtained data were processed using SPSS version 15 (SPSS Inc., Chicago, IL, USA). Quantitative data were expressed as means \pm SD while qualitative data were expressed as numbers and percentages (\%).Chi square $\left({ }^{2}\right)$ and Fisher's exact tests were used to test significance of difference between qualitative variables. Unpaired Student $t$ test and analysis of variance (ANOVA) was used to test significance of difference between two or more qualitative variables respectively. Spearman correlation coefficient (r) was used to analyze correlation between different quantitative variables. ROC (Receiver Operating Characteristic) curve was used to set a cut off value for IGF and IGF BP-3 for detection of coronary artery disease. A probability value of p-value $<0.05$ was considered statistically significant.

\section{RESULTS}

The current study aimed to determine the role of IGF-1 and IGFBP-3 in patients with CAD compared to healthy controls. It included 62 patients presented with CAD attending Suez Canal University Hospital in Ismailia and 30 apparently healthy controls. The mean age of CAD patients was $54.56 \pm 8.9$ years, with a range of $36-75$ years. Controls' age ranged $36-73$ years, with a mean of $49.6 \pm 10.2$ years. 
There was no significant difference between patients and control groups regarding to smoking, hypertension and diabetes mellitus $(\mathrm{P}>0.05)$. Coronary artery disease was more frequent among males compared to females $(67.7 \%$, versus $32.3 \%$ respectively). Both groups were matched for age and sex with no significant difference between patients and control regarding to smoking, hypertension and diabetes mellitus ( $\mathrm{p}$ value $>0.05$ ) as shown in table (1). Table (2) showed that TC, LDLc, and TAG were significantly higher, while HDLc was significantly lower in patients than controls. Table (3) showed that the mean IGF-1 was significantly higher among controls group $(212.5 \pm 109.1 \mathrm{ng} / \mathrm{ml})$ compared to patients group $(129.5 \pm 66.2 \mathrm{ng} / \mathrm{ml})$ $(\mathrm{p}=0.001)$. Moreover, the mean IGFBP-3 was higher among controls group $(6.4 \pm 2.3 \mathrm{ng} / \mathrm{ml})$ than patients group $(4.4 \pm 1.6 \mathrm{ng} / \mathrm{ml})$, with significant difference $(\mathrm{p}=0.001)$. Table (4) showed severity of the disease where $48.4 \%$ of patients had 3 stenosed vessels, $21 \%$ had 2 stenosed vessels while $30.6 \%$ had one vessel affected. The mean percent of stenosis was $74.7 \pm 14.2 \%$. Table (5) showed the correlation between the means of IGF-1 and IGFBP-3 in the patients group and the severity of disease. IGF-1 and IGFBP-3 were lower in the group of three affected vessels but there was no significant correlation between both parameters and severity of the disease. Table (6) showed significant correlation between IGF-1 and HDLc ( $p$-value $=0.046)$ in patients group while no significant correlation between IGF-1 and age, lipid profile, and percentage of stenosis in both groups. Table (7) showed that there was no significant correlation between IGFBP-3 and age, lipid profile, and percentage of stenosis in both groups. Based on receiver operating characteristic (ROC) curve, we calculated best cut off points for investigated parameters (table 8).

Table (1): Comparison between both groups regarding risk factors

\begin{tabular}{|c|c|c|}
\hline Variables & $\begin{array}{l}\text { Patient group } \\
(n=62)\end{array}$ & $\begin{array}{l}\text { Control group } \\
(n=30)\end{array}$ \\
\hline Age (years)m, Mean \pm SD & $54.56 \pm 8.9$ & $49.6 \pm 10.2$ \\
\hline $\begin{array}{ll}\text { Sex } & \text { Male } \\
& \text { Female }\end{array}$ & $\begin{array}{l}67.7 \% \\
32.3 \%\end{array}$ & $\begin{array}{l}60 \% \\
40 \%\end{array}$ \\
\hline Smoking & $\begin{array}{l}58.1 \% \\
41.9 \%\end{array}$ & $\begin{array}{l}40 \% \\
60 \%\end{array}$ \\
\hline Diabetes & $\begin{array}{l}41.9 \% \\
58.1 \%\end{array}$ & $\begin{array}{l}36.7 \% \\
63.3 \%\end{array}$ \\
\hline $\begin{array}{ll}\text { Hypertension } & \text { yes } \\
\text { no }\end{array}$ & $\begin{array}{l}51.6 \% \\
48.4 \%\end{array}$ & $\begin{array}{l}40 \% \\
60 \%\end{array}$ \\
\hline
\end{tabular}

No statistically significant difference ( $p$-value $>0.05$ for each) 
Table (2): Comparison between both groups regarding lipid profile

\begin{tabular}{|c|c|c|c|c|}
\hline \multicolumn{2}{|l|}{ Variables } & $\begin{array}{l}\text { CAD patients } \\
\text { group } \\
(n=62)\end{array}$ & $\begin{array}{l}\text { Control } \\
\text { group } \\
(\mathbf{n}=\mathbf{3 0})\end{array}$ & p-value \\
\hline \multirow{2}{*}{$\begin{array}{l}\text { HDLc } \\
(\mathrm{mg} / \mathrm{dl})\end{array}$} & Mean \pm SD & $40.4 \pm 8.6$ & $46.15 \pm 8.9$ & \multirow[t]{2}{*}{$0.004 *$} \\
\hline & Range & $22-68$ & $22-65$ & \\
\hline \multirow{2}{*}{$\begin{array}{l}\text { Total Cholesterol } \\
(\mathrm{mg} / \mathrm{dl})\end{array}$} & Mean \pm SD & $230.0 \pm 65.0$ & $174.13 \pm 59.9$ & \multirow[t]{2}{*}{$0.001 *$} \\
\hline & Range & $102-362$ & $97-300$ & \\
\hline \multirow{2}{*}{$\begin{array}{l}\text { Triacylglycerol } \\
(\mathrm{mg} / \mathrm{dl})\end{array}$} & Mean \pm SD & $178.5 \pm 62.4$ & $146.1 \pm 40.3$ & \multirow[t]{2}{*}{$0.01 *$} \\
\hline & Range & $85-400$ & $85-305$ & \\
\hline \multirow{2}{*}{$\begin{array}{l}\text { LDLc } \\
(\mathrm{mg} / \mathrm{dl})\end{array}$} & Mean \pm SD & $126.7 \pm 42.0$ & $104.3 \pm 43.8$ & \multirow[t]{2}{*}{$0.02 *$} \\
\hline & Range & $55-219$ & $42-188$ & \\
\hline
\end{tabular}

HDLc $=$ High density lipoprotein cholesterol. LDLc $=$ Low density lipoprotein cholesterol.

$*$ Significant difference $(\mathrm{p}$-value $<0.05)$

Table (3): Comparison between both groups regarding IGF-1 and IGFBP-3

\begin{tabular}{|l|l|l|l|l|}
\hline \multicolumn{2}{|l|}{ Parameters } & $\begin{array}{l}\text { Study group } \\
(\mathbf{n = 6 2})\end{array}$ & $\begin{array}{l}\text { Control group } \\
(\mathbf{n = 3 0})\end{array}$ & p-value \\
\hline \multirow{2}{*}{$\begin{array}{l}\text { IGF-1 } \\
(\mathrm{ng} / \mathrm{ml})\end{array}$} & Mean \pm SD & $129.5 \pm 66.2$ & $212.5 \pm 109.1$ & $0.001^{*}$ \\
\cline { 2 - 4 } $\begin{array}{l}\text { IGFBP-3 } \\
(\mathrm{ng} / \mathrm{ml})\end{array}$ & Range & $25-351$ & $30-388$ & \\
\cline { 2 - 4 } & Mean \pm SD & $4.4 \pm 1.6$ & $6.4 \pm 2.3$ & $0.001^{*}$ \\
\hline
\end{tabular}

* Statistically significant difference (p-value $<0.05)$.

IGF-1 = insulin like growth factor-1.

IGFBP-3 = Insulin like growth factor Binding Protein-3

Table (4): Distribution of patients group according to coronary angiography findings

\begin{tabular}{|l|l|l|l|}
\hline \multicolumn{2}{|l|}{ Variables } & $\begin{array}{l}\text { Number } \\
(\mathbf{n = 6 2 )}\end{array}$ & Percentage \\
\hline \multirow{3}{*}{ Severity } & 1 vessels & 19 & $30.6 \%$ \\
\cline { 2 - 4 } & 2 vessels & 13 & $21.0 \%$ \\
\cline { 2 - 4 } & 3 vessels & 30 & $48.4 \%$ \\
\hline \multirow{2}{*}{ Percence of stenosis } & Mean \pm SD & $74.7 \pm 14.2$ \\
\cline { 2 - 4 } & & \multicolumn{2}{|c}{} \\
\cline { 2 - 4 }
\end{tabular}


Table (5): Relation between IGF-1, IGFBP-3 and severity of CAD in patients group:

\begin{tabular}{|l|l|l|l|}
\hline \multirow{2}{*}{ Parameters } & \multicolumn{3}{|l|}{ Severity of disease } \\
\cline { 2 - 4 } & 1 vessel & 2 vessels & 3 vessels \\
\hline $\begin{array}{l}\text { IGF }(\mathrm{ng} / \mathrm{ml}) \\
\text { Mean } \pm \text { SD }\end{array}$ & $137.1 \pm 68.7$ & $148.2 \pm 78.9$ & $116.6 \pm 56.7$ \\
\hline $\begin{array}{l}\text { IGFBP-3 }(\mathrm{ng} / \mathrm{ml}) \\
\text { Mean } \pm \text { SD }\end{array}$ & $4.3 \pm 2.0$ & $5.2 \pm 1.7$ & $4.0 \pm 1.3$ \\
\hline
\end{tabular}

No statistically significant difference ( $p$-value $>0.05)$

Table (6): Correlation between IGF-1 and age, lipid profile, and percentage of stenosis in each of the two studies groups

\begin{tabular}{|l|l|l|l|l|}
\hline \multirow{2}{*}{ Variables } & \multicolumn{2}{|l|}{ Patients group, $(\mathbf{n}=\mathbf{6 2})$} & \multicolumn{2}{l|}{ Control group, $(\mathbf{n}=\mathbf{3 0})$} \\
\cline { 2 - 5 } & $\mathbf{R}$ & $\mathbf{p}$-value & $\mathbf{r}$ & $\mathbf{p}$-value \\
\hline Age, years & 0.001 & $0.9(\mathrm{NS})$ & 0.23 & $0.205(\mathrm{NS})$ \\
\hline HDLc, mg/dl & 0.254 & $0.046^{*}$ & 0.22 & $0.24(\mathrm{NS})$ \\
\hline Total Cholesterol, & 0.09 & $0.518(\mathrm{NS})$ & -0.129 & $0.49(\mathrm{NS})$ \\
\hline Triacylglycerol, & 0.11 & $0.39(\mathrm{NS})$ & 0.06 & $0.72(\mathrm{NS})$ \\
\hline LDLc,, $\mathrm{mg} / \mathrm{dl}$ & -0.08 & $0.5(\mathrm{NS})$ & -0.20 & $0.26(\mathrm{NS})$ \\
\hline Percent of stenosis & 0.09 & $0.47(\mathrm{NS})$ & - & - \\
\hline
\end{tabular}

$\mathrm{HDLc}=$ High density lipoprotein cholesterol. LDLc $=$ Low density lipoprotein cholesterol.

$\mathrm{r}$ :Spearman Correlation coefficient

NS: no significant difference (p-

value $>0.05$

*Significant difference $(\mathrm{p}$-value $<0.05)$

Table (7): Correlation between IGFBP-3 and age, lipid profile, and percent of stenosis in both groups

\begin{tabular}{|l|l|l|l|l|}
\hline \multirow{2}{*}{ Variables } & \multicolumn{2}{|l|}{$\begin{array}{l}\text { CAD group } \\
(\mathbf{n = 6 2 )}\end{array}$} & $\begin{array}{l}\text { Control group } \\
(\mathbf{n = 3 0 )}\end{array}$ \\
\cline { 2 - 5 } & $\mathbf{r}$ & $\mathbf{p}-$-value & $\mathbf{r}$ & p-value \\
\hline Age, years & 0.297 & $0.11(\mathrm{NS})$ & 0.29 & $0.111(\mathrm{NS})$ \\
\hline HDLc, mg/dl & -0.067 & $0.60(\mathrm{NS})$ & -0.17 & $0.344(\mathrm{NS})$ \\
\hline Total Cholesterol , mg/dl & 0.167 & $0.19(\mathrm{NS})$ & -0.12 & $0.52(\mathrm{NS})$ \\
\hline Triacylglycerol, $\mathrm{mg} / \mathrm{dl}$ & 0.213 & $0.09(\mathrm{NS})$ & -0.16 & $0.39(\mathrm{NS})$ \\
\hline LDLc,, $\mathrm{mg} / \mathrm{dl}$ & 0.054 & $0.67(\mathrm{NS})$ & -0.04 & $0.83(\mathrm{NS})$ \\
\hline Percent of stenosis & 0.06 & $0.6(\mathrm{NS})$ & - & - \\
\hline
\end{tabular}

$\mathrm{HDLc}=$ High density lipoprotein cholesterol. LDLc $=$ Low density lipoprotein cholesterol.

$\mathrm{r}$ :Spearman Correlation coefficient $\quad$ NS: no significant difference ( $\mathrm{p}$-value $>0.05$ ) 
Table (8): Sensitivity and specificity of investigated parameters by using Receiver Operating Characteristic (ROC) curve

\begin{tabular}{|l|l|l|l|l|}
\hline Parameters & Cut-off & Sensitivity & Specificity & $\begin{array}{l}\text { Area under } \\
\text { ROC curve }\end{array}$ \\
\hline IGF-1 & 173 & $71 \%$ & $63 \%$ & 0.72 \\
\hline IGFBP-3 & 5.1 & $77 \%$ & $77 \%$ & 0.77 \\
\hline
\end{tabular}

\section{DISCUSSION}

Coronary artery diseases (CAD) constitute a major health problem in many parts of the world and are an important cause of morbidity and mortality. It is predicted that by the year 2020, CAD will be the main cause of disability worldwide ${ }^{(\mathbf{4 5})}$.

There is evidence that IGF-1 plays a role in cardiovascular disorders such as atherosclerosis ${ }^{(\mathbf{4 6 , 4 7 )} \text {. }}$

The present study was undertaken to determine the relationship between the levels of IGF-1 and IGFBP-3 with coronary atherosclerosis in patients living in Suez canal area attending at Cardiology Unit, Suez Canal University Hospital. There was no significant difference between patients group and control group regarding to smoking, hypertension and diabetes mellitus $\quad(\mathrm{p}>0.05)$ However, significant differences were found between both groups regarding to HDLc, LDLc, TC, and TAG $(\mathrm{p}<0.004, ? 0.02,<0.001$ and $<0.01$ respectively). Similar results have been reported by other studies ${ }^{(\mathbf{4 8 , 4 9})}$. Shankar et al., ${ }^{(50)}$ reported significant difference between CAD patients and controls $(p<0.001)$ as regard TC, LDLc and TAG but no significant difference between both groups regarding to $\mathrm{HDLc}^{(\mathbf{5 0 )}}$. In a prospective cardiovascular Munster study, HDLc in CHD patients was reported to be lower as compared to that in controls but not statistically significant ${ }^{(51)}$.

Jousilahti et al., ${ }^{(52)}$ stated that in male cases there was an increased levels around age 45 to 50 years, while in female cases, there was increase that continues sharply until age of 60 to 65 years ${ }^{(52)}$.

In the present study, there was significant difference between both groups regarding IGF-1 and IGFBP-3 $(p<0.001$ for each) which were lower in patients group than control. In fact, these results were in agreement with previous studies which demonstrated decreased circulating levels of total or free IGF-1 or IGFBP-3 in patients with $\mathrm{CAD}^{(27,53)}$. Bøtker et al. (1997) and Ruotolo et al. (2000) demonstrated that circulating levels of IGF-1 and/or IGFBP were decreased in patients with manifest $\mathrm{CAD}$ due to decreased activity of the GH-IGF-1 axis ${ }^{(54,55)}$. Kawachi et al. (2005) found that increased serum IGF-1 and IGFBP-3 levels were associated with CAD in Japanese men $^{(28)}$, while Juulet al. (2002) demonstrated that the low IGF-1 and high IGFPP-3 predicted increased risk of ischemic heart disease in a case control study which was conducted in a large 
prospective study on cardiovascular epidemiology ${ }^{(\mathbf{2 6})}$.

The present study showed no relation between IGF-1, IGFBP-3 and severity of IHD in the study group. Schuler-Lüttmann et al. (2000) examined the associations of IGF-1 and IGFBP-3 with three coronary scores: a vessel score, a stenosis score, and an extent score and found IGFBP3 to be significantly inversely associated with all three scores. They also reported that IGF-1 was inversely associated with arteriosclerosis in unadjusted analysis, but in multivariate analysis the association between vessel score and IGF-1 became positive and marginally significant and the associations for stenosis score and extent score became non-significant ${ }^{(27)}$. SchulerLüttmann et al. (2000) speculated that IGFBP-3 may be part of the insulin resistance cluster, which would underlie the physiologic basis of the associations between IGFBP-3 and arteriosclerosis ${ }^{(27)}$.

Burchardt et al. (2010) noticed significantly elevated circulating levels of IGF-1 in patients with significant obstructive lesions in all three coronary arteries in contrast to those without changes ${ }^{(29)}$.

In this study there was significant inverse correlation between IGF-1 and HDLc ( $\mathrm{r}=-0.254, \mathrm{P}=0.046)$, while there was no significant correlation between IGF-1 and TC and LDLc ( $\mathrm{P}>0.5 \quad \&>0.3$ respectively). These results are in accordance with a study of elderly men and women, performed by Ceda et al. (1998) who found no association between IGF-1 and total or LDLc ${ }^{(56)}$. On the other hand, in a dietary intervention study, Prewitt et al. (1992) found significant inverse associations between IGF-1 and TC and LDLc in hypercholesterolemic women with a mean age of 32 years (range, 20-48 years) both after a 4week high-fat diet and after a 20 -week low-fat diet. They did not find an association between IGF-1 and HDLc (57). Also, in a clinical study of 132 healthy elderly men and women, laura et al. (2004) found a significant positive correlation between IGFBP-3 and HDLc after adjustment for age and body mass index but no association between either IGF-1 and TC or LDLc or IGFBP-3 and TC or LDLc $^{(58)}$. In a large cross-sectional study of men and women in the Singapore Chinese Health Study ${ }^{(59)}$, there were positive correlations of TC and LDLc with both IGF-1 and IGFBP-3, but there were no associations for HDLc. Colangelo et al. (2004), stated that their finding of a positive correlation between HDLc and IGFBP-3 suggests that growth hormone, which activates IGF formation and secretion, plays a role in lipid metabolism ${ }^{(58)}$.

In conclusion, IGF-1 and IGFBP3 may be used as risk factors in CAD in Egyptian patients in Suez Canal area. Further studies using larger series and different population might lead to more significant results.

\section{REFERENCES}

1. Lioyd-Jones D., Adams R., Carnethon M., Desimone G., Ferguson TB.andFlegal $K$. (2008): American Heart Association Statistics Committee and stroke Statistics Subcommitte. Heart disease and 
stroke Statistics-2009 Update. A report from the American Heart Association Statistics Committee and stroke Statistics Subcommitte. Circulation 2008 Dec 15.

2. Rabelo LM. (2001): Atherosclerotic risk factors in adolescence. J. Pediatr. (Rio J).77(Supl.2): s153-s64.

3. Lisa $M$, Haleagrahara $N$, Chakravarthi S. (2011): Insulin like growth factor-1 (IGF-1) reduces ischemic changes and increases circulating angiogenic factors in experimentally-induced myocardial infarction in rats. Vascular Cell 3(1):13.

4. Clemmons DR. (1998): Role of insulin-like growth factor binding proteins in controlling IGF actions. Mol. Cell. Endocrinol., 140(1-2):19-24.

5. Le Roith D, Bondy C, Yakar S, Liu JL and Butler A (2001): The somatomedin hypothesis: Endocr. Rev., 22(1): 53-74.

6. Brahm H, Phiel-Aulin K, Saltin B and Ljunghall S (1997): Net fluxes over working thigh of hormones, growth factors and biomarkers of bone metabolism during short lasting dynamic exercise. Calcif. Tissue Int., 60(2): 175-180.

7. Baxter, R. C. (1990): Circulating levels and molecular distribution of the acid-labile $(\alpha)$ subunit of the high molecular weight insulin-like growth factor-binding protein complex. J. Clin. Endocrinol.Metab.,70(5): 13471353.

8. Conti E, Musumeci MB, De Giusti M, Dito E, Mastromarino
V, Autore C, Volpe M. (2011): IGF-1 and atherothrombosis: relevance to pathophysiology and therapy. Clinical Science (London) 120(9):377-402.

9. Holly J and Perks C. (2006): The role of insulin-like growth factor binding proteins. Neuroendocrinology 83(3-4): 154-160.

10. Duerr RL, Huang S, Miraliakbar HR, Clark R, Chien KR, and Ross J, Jr. (1995): Insulin-like growth factor-1 enhances ventricular hypertrophy and function during the onset of experimental cardiac failure. J. Clin. Invest., 95(2):619627.

11. Kotlyar AA, Vered Z, Goldberg I, Chouraqui $P$, Nas D, Fridman E, Chen-Levy Z, Fytlovich S, Sangiorgi G, Spagnoli LG, Orlandi A, Savion N, Eldar M, Scheinowitz $M$. (2001): Insulin-like growth factor I and II preserve myocardial structure in post-infarct swine. Heart 86(6):693-700.

12. Ren J, Samson WK, and Sowers JR (1999): Insulin-like growth factor I as a cardiac hormone: physiological and pathophysiological implications in heart disease. J. Mol. Cell. Cardiol., 31(11):2049 -2061.

13. Donath MY, Sutsch G, Yan XW, Piva B, Brunner HP, Glatz Y, Zapf J, Follath F, Froesch ER, and Kiowski W. (1998): Acute cardiovascular effects of insulin- like growth factor I in patients with chronic heart failure. J. Clin. Endocrinol. Metab., 83(9):3177-3183. 
14. Friehs I, Stamm C, Cao-Danh H, McGowan FX and Del Nido PJ. (2001): Insulin-like growth factor-1 improves post ischemic recovery in hypertrophied hearts. Ann. Thorac. Surg., 72(5):16501656.

15. Janssen JA, Stolk RP, Pols HA, Grobbee DE, and Lamberts SW. (1998): Serum total IGF-I, free IGF-, and IGFBP-1 levels in an elderly population: relation to cardiovascular risk factors and disease. Arterioscler. Thromb. Vasc. Biol., 18(7):277-282.

16. Janssen JA and Lamberts SW. (2002): The role of IGF-I in the development of cardiovascular disease in type 2 diabetes mellitus: is prevention possible? Eur. J. Endocrinol., 146(4):467477.

17. Van den Beld AW, Bots ML, Janssen JA, Pols HA, Lamberts SW, and Grobbee DE. (2003): Endogenous hormones and carotid atherosclerosis in elderly men. Am. J. Epidemiol., 157(1):25-31

18. Schneider HJ, Klotsche J, Saller B, Bohler S, Sievers C, Pittrow D, Ruf G, Marz W, Erwa W, Zeiher AM, Silber S, Lehnert H, Wittchen HU, and Stalla GK. (2008): Associations of age-dependent IGF-I SDS with cardiovascular diseases and risk conditions: cross-sectional study in 6773 primary care patients. Eur. J. Endocrinol., 158(2):153161.

19. Martin RM, Gunnell D, Whitley E, Nicolaides A, Griffin M, Georgiou N, Davey SG, Ebrahim S, and Holly JM.
(2008): Associations of insulinlike growth factor (IGF)-I, IGFII, IGF binding protein (IGFBP) 2 and IGFBP-3 with ultrasound measures of atherosclerosis and plaque stability in an older adult population. J. Clin. Endocrinol. Metab., 93(4):1331-1338.

20. Andreassen M, Raymond I, Kistorp C, Hildebrandt P, Faber $J$ and Kristensen LØ (2009): IGF1 as predictor of allcause mortality and cardiovascular disease in an elderly population. Eur. J. Endocrinol., 160(1): 25-31.

21. Kaplan RC, McGinn AP, Pollak MN, Kuller LH, Strickler HD, Rohan TE, Cappola AR, Xue X, and Psaty BM. (2007): Association of total insulin-like growth factor-I, insulin-like growth factor binding protein-1 (IGFBP-1), and IGFBP3 levels with incident coronary events and ischemic stroke. J. Clin. Endocrinol. Metab., 92(4):1319-1325.

22. Laughlin GA, Barrett-Connor E, Criqui MH, and KritzSilverstein D. (2004): The prospective association of serum insulin-like growth factor I (IGFI) and IGF-binding protein-1 levels with all cause and cardiovascular disease mortality in older adults: the Rancho Bernardo Study. J. Clin. Endocrinol. Metab., 89(1):114120.

23. Lawlor DA, Ebrahim S, Smith GD, Cherry L, Watt $P$, and Sattar N. ( 2008): The association of insulin-like growth factor 1 (IGF-1) with incident 
coronary heart disease in women: Findings from the prospective British Women's Heart and Health Study. Atherosclerosis 201(1):198-204.

24. Page JH, Ma J, Pollak M, Manson JE, and Hankinson SE. (2008): Plasma insulin like growth factor 1 and bindingprotein 3 and risk of myocardial infarction in women: a prospective study. Clin. Chem., 54(10):1682-1688.

25. Saydah S, Graubard B, Ballard-Barbash R, and Berrigan D. (2007): Insulin-like growth factors and subsequent risk of mortality in the United States. Am. J. Epidemiol., 166(5):518-526.

26. Juul A, Scheike T, Davidsen M, Gyllenborg $\mathbf{J}$, and Jorgensen $\mathbf{T}$. (2002): Low serum insulin-like growth factor I is associated with increased risk of ischemic heart disease: a population-based casecontrol study. Circulation 106(8):939- 944.

27. Schuler-Lüttmann S, Mönnig G, Enbergs A, Schulte H, Breithardt G, Assmann G, Kerber $S$ and von Eckardstein A. (2000): Insulin-like growth factor-binding protein-3 is associated with the presence and extent of coronary arteriosclerosis. Arterioscler. Thromb. VascBiol., 20(4): e10e15.

28. Kawachi S, Takeda N, Sasaki A, Kokubo Y, Takami K, Sarui H, Hayashi M, Yamakita N, Yasuda K. (2005): Atherosclerosis and lipoproteins: Circulating Insulin-Like Growth
Factor-1 and Insulin-Like Growth Factor Binding Protein-3 are associated with early carotid atherosclerosis Arterioscler. Thromb. Vasc. Biol., 25(3):617621.

29. Burchardt P, GozdzickaJozefiak A, Zurawski J, Nowak W, Durzynska J, Link R, Grotowski T, Siminiak T. (2010): Are elevated levels of IGF-1 caused by coronary arteriesoclerosis?: Molecular and clinical analysis. Protein J., 29(8): 538-544.

30. Delafontaine $\mathbf{P}$, Song $\mathbf{Y H}$ and Li Y. (2004): Expression, regulation, and function of IGF-1, IGF-1R, and IGF-1 binding proteins in blood vessels. Arterioscler. Thromb. VascBiol., 24(3): 435-444.

31. Huynh K, McMullen, JR, Julius TL, Tan JW, Love JE, Cemerlang N, Kiriazis $\mathrm{H}$, Du XJ, and Ritchie, R. H. (2010): Cardiac-specific insulin-like growth factor 1 receptor transgenic expression protects against cardiac fibrosis and diastolic dysfunction in a mouse model of diabetic cardiomyopathy. Diabetes 59(6) 1512-20.

32. Anversa P, (2005): Aging and longevity: the IGF-1 enigma. Circ. Res., 97(5): 411-414.

33. Brugts, M. P., Van Den Beld, A. W.,Hofland, L. J., Van Der Wansem, K., van Koetsveld, P. M., Frystyk, J., Lamberts, S.W. and Janssen, J. A. (2008): Low circulating insulin-like growth factor I bioactivity in elderly men is associated with increased 
mortality. J. Clin. Endocrinol. Metab., 93(7): 2515-2522.

34. Friedrich N, Haring $R$, Nauck M, Lüdemann J, Rosskopf $D$, Spilcke-Liss E, Felix SB, Dörr M, Brabant G, Völzke H, Wallaschofski H. (2009): Mortality and serum insulin-like growth factor (IGF)-I and IGF binding protein 3 concentrations. J. Clin. Endocrinol. Metab., 94(5): 1732-1739.

35. Lam CS, Chen MH, Lacey SM, Yang Q, Sullivan LM, Xanthakis V, Safa R, Smith HM, Peng X, Sawyer DB, Vasan RS. (2010): Circulating insulin-like growth factor-1 and its binding protein-3: metabolic and genetic correlates in the community. Arterioscler. Thromb.Vasc. Biol., 30(7): 14791484.

36. van Rijn MJ, Slooter AJ, Bos MJ, Catarino CF, Koudstaal PJ, Hofman A, Breteler MM, van Duijn CM. (2006): Insulinlike growth factor I promoter polymorphism, risk of stroke, and survival after stroke: the Rotterdam study. J. Neurol. Neurosurg. Psychiatry 77(1): 2427.

37. Yazdanpanah M, Rietveld I, Janssen JA, Njajou OT, Hofman A, Stijnen T, Pols HA, Lamberts SW, Witteman JC, van Duijn CM. (2006): An insulin-like growth factor-I promoter polymorphism is associated with increased mortality in subjects with myocardial infarction in an elderly Caucasian population.
Am. J. Cardiol., 97(9): 12741276.

38. Kaplan RC, McGinn AP, Pollak MN, Kuller L, Strickler HD, Rohan TE, Xue X, Kritchevsky SB, Newman AB, Psaty BM. (2008): Total insulin like growth factor 1 and insulinlike growth factor binding protein levels, functional status, and mortality in older adults. J. Am. Geriatr. Soc., 56(4): 652-660.

39. van Bunderen CC, van Nieuwpoort IC, van Schoor NM, Deeg DJ, Lips P, Drent ML. (2010): The association of serum insulin-like growth factor-I with mortality, cardiovascular disease, and cancer in the elderly: a population-based study. J. Clin. Endocrinol.Metab., 95(10): 46164624.

40. Trinder P. (1969): Determination of glucose in blood using glucose oxidase with an alternative oxygen receptor, Ann. Clin. Biochem., 6:24-26.

41. Flegg HM (1973): An investigation of the determination of serum cholesterol by an enzymatic method. Ann. Clin. Biochem., 10:79-84.

42. Fossati P, Prencipe L. (1982): Serum Triglycerides determined colorimetrically with an enzyme that produces hydrogen peroxide. Clin. Chem., 28(10):2077-2080.

43. Izzo C., Grillo F. and Murador E. (1981): Improved method for determination of high-density lipoprotein cholesterol: Isolation of high density lipoproteins by use of polyethylene glycol 6000 . Clin. Chem., 27 (3): 371-374. 
44. Friedewald WT; Levy RI and Fredrickson DS, (1973): Estimation of the concentration of LDL cholesterol in plasma without use of the preparative ultracentrifuge. Clin. Chem., 18(6): 499.

45. WHO (October 2008): The top 10 causes of death. Fact Sheet No.310.

46. Le Roith D. (1997): Seminars in medicine of the Beth Israel Deaconess Medical Center. Insulin-like growth factors. N. Engl. J. Med., 336(9):633-640.

47. Dean R, Bach L, Burrell Land Histochem J. (2003): Upregulation of cardiac insulinlike growth factor-I receptor by ACE inhibition after myocardial infarction: potential role in remodeling. J. Histochem. Cytochem., 51(6):831-9.

48. Cullen P. (2000): Evidence that triglycerides are independent coronary heart disease risk factors. Am. J. Cardiol., 86(9): 943-9.

49. Jeppesen J, Hein HO, Suadicani P, Gyntelberg F. (1998): Triglyceride concentration and ischemic heart disease- an eight year follow up in the Copenhagen Male study. Circulation 97(11): 1029-36.

50. Shankar V, Kaur H, Dahiya K and Gupta MS (2008): Comparison of Fasting and Postprandial Lipid Profile in Patients of Coronary Heart Disease. Bombay Hospital Journal 50(3):445 - 9.

51. Assmann G, Cullen $P$ and Schulte H. (1998): The MunsterHeart Study (PROCAM)
- results of follow up at 8years. Eur. Heart J., 19(Suppl., A): A2A11.

52. Jousilahti $P$, Vartiainen E, Tuomilehto J, Puska P. (1999): Sex, age, cardiovascular risk factors, and coronary heart disease. Circulation 99(9):11651172.

53. Conti E, Andreotti F, Sciahbasi A, Riccardi P, Marra G, Menini E, Ghirlanda $G$ and Maseri A. (2001): Markedly reduced insulin-like growth factor-1 in the acute phase of myocardial infarction. J. Am. Coll. Cardiol., 38(1): 26-32.

54. Bøtker HE, Skjaerbaek C, Eriksen UH, Schmitz O, Orskov H. (1997): Insulin-like growth factor-I, insulin, and angina pectoris secondary to coronary atherosclerosis, vasospasm, and syndrome X. Am. J. Cardiol.,79(7): 961-963.

55. Ruotolo $G$, Båvenholm $P$, Brismar K, Eféndic S, Ericsson $C$, de Faire $U$, Nilsson $J$ and Hamsten A. (2000): Serum insulin-like growth factor-I level is independently associated with coronary artery disease progression in young male survivors of myocardial infarction: beneficial effects of bezafibrate treatment. J. Am. Coll. Cardiol., 35(3): 647-654.

56. Ceda GP, Dall'Aglio E, Magnacavallo A, Vargas N, Fontana V, Maggio M, Valenti G, Lee PD, Hintz RL, Hoffman AR. (1998): The insulin-like growth factor axis and plasma lipid levels in the elderly. J. Clin. 
Endocrinol. Metab., 83(2):499502.

57. Prewitt TE, Unterman TG, Glick R, Cole TG, Schmeisser $D$, Bowen PE, Langenberg $P$. (1992): Insulin-like growth factor I and low-density-lipoprotein cholesterol in women during high- and low-fat feeding. Am. J. Clin. Nutr., 55(2):381.

58. Colangelo LA, Liu K, Gapstur SM; (2004): Insulin-like Growth Factor-1, Insulin-like Growth Factor Binding Protein-3, and cardiovascular disease risk factors in young black men and white men The CARDIA Male Hormone Study. Am. J. Epidemiol., 160 (8): 750-757.

59. Probst-Hensch NM, Wang $\mathrm{H}$, Goh VH, Seow A, Lee HP, Yu MC. (2003): Determinants of circulating insulin-like growth factor I and insulin-like growth factor binding protein 3 concentrations in a cohort of Singapore men and women. Cancer Epidemiol. Biomarkers Prev., 12(8):739-46. 


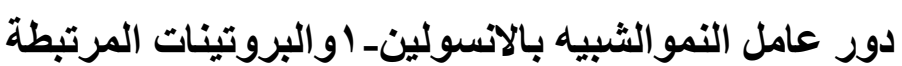

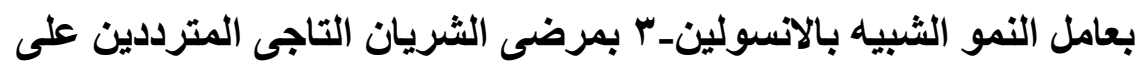

\section{مستثفى جامعه قناه السويس الثريان التراج}

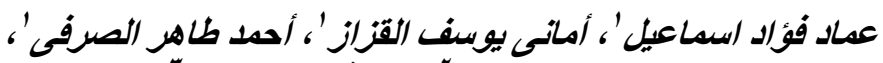

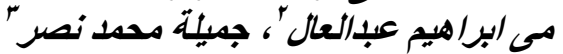

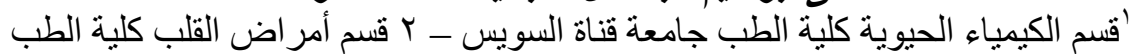

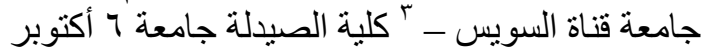

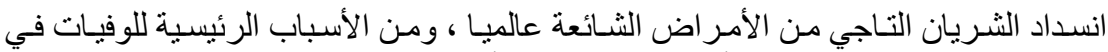

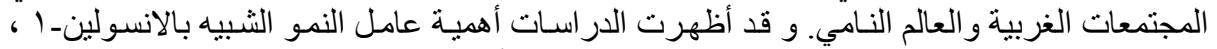

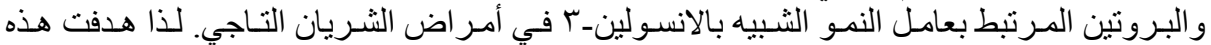

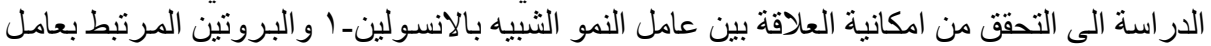

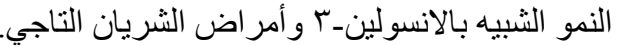

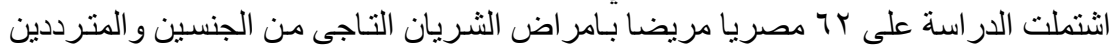

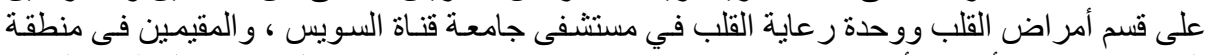

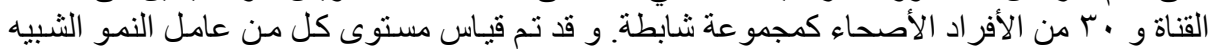

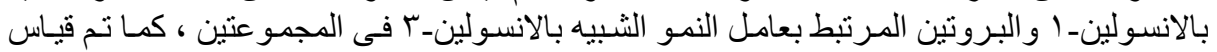

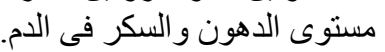

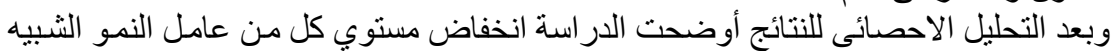

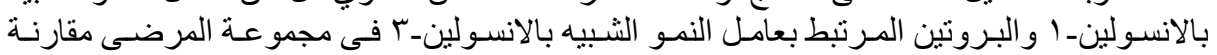

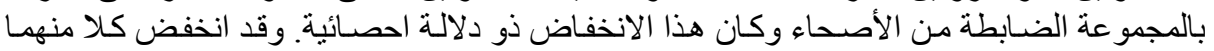

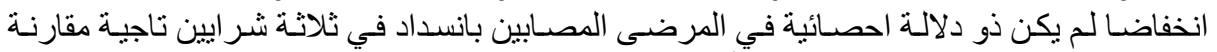

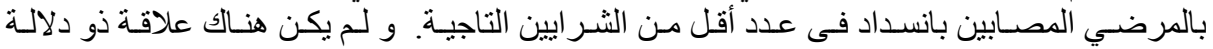

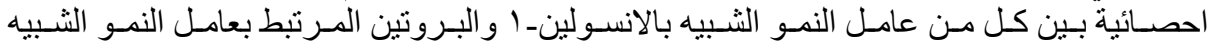

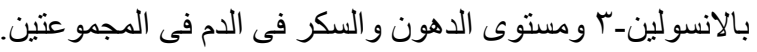

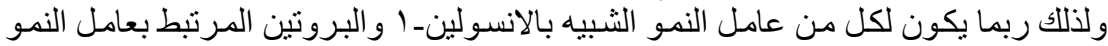

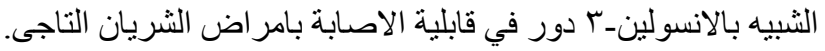

